\author{
Rafał Muster \\ Uniwersytet Śląski w Katowicach \\ (D) https://orcid.org/0000-0001-8255-7803
}

\title{
Sprawozdanie z działalności Instytutu Socjologii za 2020 rok
}

W 2020 roku pracownicy Instytutu Socjologii Uniwersytetu Śląskiego pomimo pandemii COVID-19, która w istotny sposób utrudniła prowadzenie badań — podejmowali szereg działań mających na celu realizację zadań naukowych (w ramach funkcjonujących zespołów badawczych) i dydaktycznych. Przede wszystkim należy zwrócić uwagę na fakt ciągłości procesu dydaktycznego. Należy podkreślić, że po wprowadzeniu ograniczeń kształcenie w Instytucie Socjologii bardzo szybko zostało przeniesione z trybu stacjonarnego w przestrzeń wirtualną. Zajęcia dydaktyczne już w marcu odbywały się z wykorzystaniem platform internetowych (Moodle, Teams). Bardzo duże wsparcie merytoryczne w zakresie przechodzenia na nowy, zdalny model kształcenia pracownicy Instytutu otrzymali od Dyrektorki Kierunków Polityki miejskie i doradztwo publiczne; Praca socjalna; Socjologia — dr Agaty Zygmunt oraz od jej Zastępczyni — dr Ewy Leśniak-Berek, prof. UŚ. Uniwersytet Śląski bardzo szybko wypracował procedury funkcjonowania zdalnego — nie tylko w zakresie realizacji procesu dydaktycznego, lecz także w zakresie prowadzenia postępowań awansowych, obron prac dyplomowych czy funkcjonowania rad naukowych.

W 2020 roku w Instytucie Socjologii podejmowano szereg działań mających na celu ugruntowanie pozycji Instytutu zarówno w kraju, jak i w środowisku międzynarodowym. Jest to szczególnie istotne w kontekście zbliżającej się ewaluacji dyscyplin naukowych.

Pracownicy Instytutu Socjologii czynnie uczestniczyli w licznych konferencjach o zasięgu krajowym i międzynarodowym. Doktor Rafał Cekiera był głównym organizatorem konferencji Wendelinaria 2020 pt. „Fizyczny dystans, społeczna 
bliskość? Przestrzeń: znaczenia, funkcje i przeobrażenia", która odbyła się w trybie online. Współorganizatorami tej konferencji były Towarzystwo Miłośników Rudzicy oraz Starostwo Powiatowe w Bielsku-Białej.

Pracownicy Instytutu Socjologii w 2020 roku opublikowali m.in. 21 artykułów w czasopismach naukowych znajdujących się w ministerialnym wykazie czasopism. Ponadto opublikowali 7 monografii; ukazała się m.in. praca dra hab. prof. UŚ Krzysztofa Bierwiaczonka i dra hab. prof. UŚ Tomasza Nawrockiego pt. Pomiędzy trauma wojny a codziennościa. Pamięć zbiorowa mieszkańców górnoślaskiej wsi Bojszowy (Wydawnictwo Naukowe Scholar), czy książka dr Barbary Lewickiej i prof. Marka S. Szczepańskiego pt. Obraz i spoteczeństwo. Społeczne ramy kultury artystycznej (Wydawnictwo Naukowe PWN).

Ponadto pracownicy Instytutu pełnili funkcje redaktorów naukowych w 3 monografiach oraz opublikowali 22 rozdziały w pracach zwartych. Na uwagę zasługują rozdziały opublikowane w prestiżowym wydawnictwie Edward Elgar Publishing przez prof. Kazimierę Wódz, dr Monikę Gnieciak i dra Witolda Mandrysza.

Generalnie należy odnotować, że pracownicy Instytutu Socjologii coraz częściej publikują w wysoko punktowanych czasopismach o zasięgu międzynarodowym. Jako przykład można podać opublikowanie przez czterech pracowników Instytutu (R. Pyka, K. Bierwiaczonek, G. Gawron, M. Suchacka) artykułu za 100 pkt. w czasopiśmie „Creativity Studies” (2020, no. 2). W tekście pt. Innovation Places: Theoretical and Methodological Remarks for Analysing Metropolitan Creativity and Innovations autorzy zaprezentowali własną koncepcję modelu teoretycznego dotyczącego funkcjonowania miejsc generujących innowacje społeczne. Model ten stanowił także element podstawy teoretycznej dla składanych dwóch wniosków grantowych w ramach projektu Horizon 2020 (w 2019 oraz 2020 roku). Aktualnie stworzony model teoretyczny podlega empirycznej weryfikacji w ramach badań prowadzonych na obszarze województwa śląskiego i we Francji (Lyon) przez Zespół Badawczy w składzie: Robert Pyka (lider), Krzysztof Bierwiaczonek, Grzegorz Gawron i Małgorzata Suchacka.

Pomimo licznych ograniczeń związanych z pandemią COVID-19 pracownicy Instytutu Socjologii umacniali współpracę międzynarodową, uczestnicząc także w stażach zagranicznych:

- dr Barbara Lewicka otrzymała stypendium Fulbright Senior Award i staż odbywała w Stanach Zjednoczonych w Columbia University (Nowy Jork). W Columbia University realizowała projekt „American Symbolic Revolution. Art and Society", którego celem była rekonstrukcja charakteru nowojorskiego środowiska artystycznego przełomu XIX i XX wieku oraz porównanie natury przemian amerykańskiego i europejskiego świata sztuki;

- dr hab. prof. UŚ Robert Pyka uzyskał stypendium Collegium Lyon, Institute for Advanced Study, a staż badawczy odbywał we Francji w University of Lyon;

- dr Rafał Cekiera otrzymał grant Visegrad Fund Grants (Intra-Visegrad Scholarship), a staż odbywał na Węgrzech w Szent István University (Gödöllő). 
W 2020 roku dr Rafał Cekiera w ramach konkursu MINIATURA 4 (NCN) uzyskał grant badawczy na realizację projektu pt. „Analiza ksiąg wotywnych jako materiału źródłowego". Natomiast dr hab. prof. UŚ Piotr Wróblewski kontynuował - jako kierownik grantu edukacyjnego — prace w projekcie pt. „Moc tradycji” (jednostką finansującą jest Ministerstwo Finansów).

Co warto podkreślić - pracownicy Instytutu Socjologii realizowali także szereg zadań, współpracując z podmiotami zewnętrznymi. Dla przykładu można wskazać następujące projekty:

— dr hab. prof. UŚ Krzysztof Bierwiaczonek i dr hab. prof. UŚ Robert Pyka przygotowali raport dla Ministerstwa Funduszy i Polityki Regionalnej pt. „Przemiany społeczne polskich miast na tle sytuacji miast europejskich i światowych - wybrane zagadnienia";

— dr Andrzej Górny przygotował ekspertyzę dotyczącą zasadności wprowadzenia Sektorowej Ramy Kwalifikacji w górnictwie;

— dr hab. Sławomira Kamińska-Berezowska pełniła funkcję eksperta naukowego w projekcie pt. „Dialog oparty o wiedzę” współfinansowanym przez OPZZ oraz ze środków Unii Europejskiej, w ramach Europejskiego Funduszu Społecznego, Działanie 2.20 „Wysokiej jakości dialog społeczny w zakresie dostosowania systemów edukacji i szkolenia do potrzeb rynku pracy";

— dr hab. prof. UŚ Rafał Muster i dr Łukasz Trembaczowski mieli współudział w opracowaniu raportu dotyczącego problematyki sprawiedliwej transformacji energetycznej w ramach powołanej Grupy Eksperckiej „Sprawiedliwa Transformacja" działającej w ramach Zespołu do spraw Rozwoju Przemysłu Odnawialnych Źródeł Energii i Korzyści dla Polskiej Gospodarki przy Ministrze Klimatu (Zarządzenie Ministra Klimatu z dnia 2 kwietnia 2020 r., poz. 2). Ponadto uczestniczyli w dyskusji online z przedstawicielami Ministerstwa Klimatu;

- dr Rafał Cekiera w trakcie festiwalu WATCH DOCS Prawa Człowieka w Filmie (Cieszyn) wygłosił wykład pt. „Fake-newsy i współczesne obiegi komunikacyjne". Ponadto w Ośrodku Doskonalenia Nauczycieli w Bielsku-Białej przeprowadził szkolenie dla nauczycieli pt. „Warsztaty z obsługi informacji w epoce fake-newsów i clickbaitu". Dla młodzieży (we współpracy z Fundacją Zróbmy To i redakcją BB) prowadził warsztaty w Bielsku-Białej pt. „Komunikacja międzykulturowa we współczesnym świecie".

$\mathrm{Na}$ odnotowanie zasługuje fakt, że prof. Marek S. Szczepański otrzymał prestiżowe wyróżnienie Ministra Nauki i Szkolnictwa Wyższego za wybitne osiągnięcia organizacyjne.

Doktor Justyna Kijonka w 2020 roku wdrażała model tutoringu do praktyki uczelnianej — w ramach projektu pozakonkursowego o charakterze wdrożeniowym pt. „Mistrzowie Dydaktyki” w ramach Programu Operacyjnego Wiedza Edukacja Rozwój współfinansowanego ze środków Europejskiego Funduszu Społecznego.

Pod przewodnictwem dra hab. prof. UŚ Adama Bartoszka zostało zorganizowanych pięć paneli dyskusyjnych (Socjo-Kato) w ramach funkcjonowania katowickiego oddziału Polskiego Towarzystwa Socjologicznego. 
Pracownicy Instytutu Socjologii w 2020 roku podejmowali szereg inicjatyw związanych z przygotowywaniem wniosków grantowych (m.in. zespół dra Witolda Mandrysza przygotowywał wniosek grantowy Horizon 2020) oraz z opracowywaniem monografii i artykułów, które zostały zgłoszone do wysoko punktowanych czasopism. Efekty tych prac będą widoczne w 2021 roku. 